\title{
Mutation and Efflux System are Responsible for Ciprofloxacin Resistance in Klebsiella pneumoniae
}

\author{
KM Zayyen ${ }^{1}$, A Rastegar-Lari², S Ghafourian ${ }^{1}$, M Taherikalani², N Sadeghifard ${ }^{1}$, FA Jalilian ${ }^{1}$, B Badakhsh ${ }^{3}$,
} A Hematian ${ }^{1}$, I Pakzad ${ }^{1}$

\begin{abstract}
The main mechanism of quinolone resistance in Klebsiella (K) pneumoniae is caused by mutation of porin-related proteins and efflux pumps. This study aimed to investigate the prevalence of ciprofloxacin-resistant $\mathrm{K}$ pneumoniae in burns patients and to understand the role of the AcrAB multidrug efflux system on minimal inhibitory concentration (MIC) of ciprofloxacin. For this reason, $52 \mathrm{~K}$ pneumoniae samples were collected from burns patients and evaluated for the mechanism of ciprofloxacin resistance. The results demonstrated that 40 isolates of $\mathrm{K}$ pneumoniae were ciprofloxacin-resistant and 35 showed the mutation on gyrA locus. By inhibition of the efflux system, the MIC yield showed a significant decrease. Therefore, it could be concluded that the high rate of mutation on the gyrA locus in combination with quinolone resistance was responsible for ciprofloxacin resistance and by inhibition of AcrA, the resistance rate showed a significant decrease in $\mathrm{K}$ pneumoniae isolated from burns patients.
\end{abstract}

Keywords: Ciprofloxacin, efflux, Klebsiella pneumoniae, mutation

\section{Las mutaciones y el sistema de eflujo son responsables de la resistencia a la ciprofloxacina en la Klebsiella pneumoniae}

KM Zayyen ${ }^{1}$, A Rastegar-Lari², S Ghafourian ${ }^{1}$, M Taherikalani², N Sadeghifard ${ }^{1}$, FA Jalilian ${ }^{1}$, B Badakhsh ${ }^{3}$, A Hematian ${ }^{1}$, I Pakzad ${ }^{1}$

\begin{abstract}
RESUMEN
El principal mecanismo de resistencia a la quinolona en las Klebsiella (K) Pneumoniae tiene como causa la mutación de las porinas y las bombas de eflujo. Este estudio tuvo por objetivo investigar la prevalencia de las $\mathrm{K}$ pneumoniae resistentes a la ciprofloxacina en pacientes con quemaduras, así como entender el papel del sistema de eflujo multidroga AcrAB en la concentración inhibitoria mínima (CIM) de la ciprofloxacina. Por esta razón, se recogieron 52 muestras de $\mathrm{K}$ pneumoniae de pacientes con quemaduras, a fin de evaluar el mecanismo de resistencia a la ciprofloxacina. Los resultados mostraron que 40 aislados de $\mathrm{K}$ pneumoniae eran resistentes a la ciprofloxacina y 35 mostraron la mutación en el locus gyrA. Con la inhibición del sistema de eflujo, el rendimiento de CIM tuvo una disminución significativa.
\end{abstract}

From: ${ }^{1}$ Clinical Microbiology Research Centre, Ilam University of Medical Sciences, Ilam, Iran, ${ }^{2}$ Department of Microbiology, School of Medicine, Iran University of Medical Sciences, Tehran, Iran and ${ }^{3}$ Research Centre and Department of Microbiology, School of Medicine, Lorestan University of Medical Sciences, Khorramabad, Iran.
Correspondence: Professor I Pakzad, Clinical Microbiology Research Centre, Ilam University of Medical Sciences, Ilam, Iran. Email: pakzadi2006@gmail.com 
Por lo tanto, se pudo concluir que la alta tasa de mutación en el locus gyrA en combinación con la resistencia a la quinolona era responsable de la resistencia a la ciprofloxacina, y por la inhibición de AcrA, la tasa de resistencia mostró una disminución significativa en las $\mathrm{K}$ pneumoniae aisladas de los pacientes con quemaduras.

Palabras clave: Ciprofloxacina, flujo, Klebsiella pneumoniae, mutación

West Indian Med J 2018; 67 (3): 227

\section{INTRODUCTION}

Klebsiella (K) pneumoniae is known as an important pathogen in both the hospital setting and the community (1). The main mechanism of quinolone resistance (qnr) in $K$ pneumoniae is caused by mutation of porin-related proteins and efflux pumps. On the one hand, the mutation of the gyrA locus is responsible for phenotypic qnr (2). On the other hand, qnr is dictated by an active efflux system, which is caused by overexpression of the AcrAB multidrug efflux system (3). Therefore, ciprofloxacinresistant $K$ pneumoniae is established by mutation of the gyrA gene as well as plasmid-mediated qnr-conferring genes (4).

Phenotypic resistance strains are related to mutation in qnr-determining region in both $K$ pneumoniae and $K$ oxytoca. The first determination of AcrAB operon in $K$ pneumoniae was found by Doménech-Sánchez et al (5).

There is no perfect study on ciprofloxacin resistance and $\mathrm{Acr} A \mathrm{~B}$ multidrug efflux system in $K$ pneumoniae, especially in burns patients in Iran. Therefore, it is reasonable to investigate the prevalence of ciprofloxacin resistant $K$ pneumoniae in burns patients and understand the role of AcrAB multidrug efflux system on minimal inhibitory concentration (MIC) of ciprofloxacin.

\section{SUBJECTS AND METHODS}

A total of $52 \mathrm{~K}$ pneumoniae isolates were collected from burns patients over six months in the Shahid Motahari hospital in Tehran, Iran. Klebsiella pneumoniae was identified by chemical standard methods. Firstly, the isolates were evaluated for susceptibility to ciprofloxacin by disc diffusion method as a guideline of the Clinical and Laboratory Standards Institute. Secondly, resistance strains were used to determine the MIC. Polymerase chain reaction (PCR) was performed to identify the gyrA, AcrA, qnrA, B and $\mathrm{S}$ by specific designed primers. Ciprofloxacin-resistant $K$ pneumoniae isolates were evaluated for mutation in gyrA by specific primers. Then, the PCR products were subjected to sequencing. By administration of CCCP (3-cholophenylhydrazone) on ciprofloxacin-resistant $K$ pneumoniae isolates, the level of MIC was determined.

\section{RESULTS}

The $52 \mathrm{~K}$ pneumoniae burn isolates comprised 35 from men and 17 from women. The results of antibiotic susceptibility demonstrated that $40 \mathrm{~K}$ pneumoniae isolates were ciprofloxacin-resistant. The AcrA gene that is responsible for the efflux system was identified in all ciprofloxacin-resistant $K$ pneumonia. In addition, our analysis showed that of the 40 ciprofloxacin-resistant $K$ pneumoniae isolates, 32 were positive for one, two or three qnr loci. In detail, $10 \%(n=4)$ contained all three qnr loci, and $2.5 \%(\mathrm{n}=1)$ showed positive results for qnrA and $\mathrm{S}$. The other findings demonstrated that $27.5 \%(\mathrm{n}=11), 25 \%(\mathrm{n}=10)$ and $15 \%(\mathrm{n}=6)$ contained qnrB-S, qnrB and qnrS, respectively. Our analysis demonstrated that $20 \%(\mathrm{n}=8)$ of ciprofloxacin-resistant $K$ pneumonia were negative for qnr loci. The results of mutation of the gyrA locus were obtained by PCR and sequencing. The results were compared with gyrA AY301163. The findings showed that 35 ciprofloxacinresistant $K$ pneumonia contained mutation at the gyrA locus which occurred in the serine amino acid with ACC going to ATC (Ser 83 IIe). For inhibition of the efflux system, CCCP was applied; then the MIC of ciprofloxacin was determined. Our results demonstrated that of 40 ciprofloxacin-resistant $K$ pneumoniae isolates, 19 showed a decrease of MIC level with two strains showing a 32 -fold decrease.

\section{DISCUSSION}

Recent data show an increase of multidrug-resistant $K$ pneumoniae $(1,2,5)$. Our findings demonstrated a $77 \%$ ciprofloxacin resistance in $K$ pnemoniae. In China, this rate was $51 \%(6)$. Therefore, our analysis emphasized the high rate of resistance in Iran. As mentioned in the Introduction, the most important mechanism to ciprofloxacin resistance is the AcrAB efflux system. So, we subjected this system for decreasing ciprofloxacin 
resistance. Our finding showed a significant decrease of MIC level, which was consistent with other studies $(7,8)$. Our results demonstrated that 32 isolates had mutation at the gyrA in one site mutation, which is different from the other studies. Prevalence of qnr loci was similar to other findings (8). Therefore, our results demonstrated that the main mechanism of ciprofloxacin resistance was via the AcrAB efflux system with a decrease of MIC level, but the other mechanisms including mutation of gyrA and the presence of qnr loci were also of importance.

\section{REFERENCES}

1. Keynan Y, Rubinstein E. The changing face of Klebsiella pneumonia infections in the community. Int J Antimicrob Agents 2007; 30: 385-9.

2. Robicsek A, Jacoby GA, Hooper DC. The worldwide emergence of plasmid-mediated quinolone resistance. Lancet Infect Dis 2006; 6: 629-40.
3. Mazzariol A, Tokue Y, Kanegawa TM, Cornaglia G, Nikaido H. High-level fluoroquinolone-resistant clinical isolates of Escherichia coli overproduce multidrug efflux protein AcrA. Antimicrob Agents Chemother 2000; 44: 3441-3.

4. Saiful Anuar AS, Mohd Yusof MY, Tay ST. Prevalence of plasmid-mediated qnr determinants and gyrase alteration in Klebsiella pneumoniae isolated from a university teaching hospital in Malaysia. Eur Rev Med Pharmacol Sci 2013; 17: 1744-7.

5. Doménech-Sánchez A, Martínez-Martínez L, Hernández-Allés S, Carmen Conejo M, Pascual A, Tomás JM et al. Role of Klebsiella pneumoniae OmpK35 porin in antimicrobial resistance. Antimicrob Agents Chemother 2003; 47: 3332-5.

6. Fu Y, Zhang W, Wang H, Zhao S, Chen Y, Meng F et al. Specific patterns of gyrA mutations determine the resistance difference to ciprofloxacin and levofloxacin in Klebsiella pneumoniae and Escherichia coli. BMC Infect Dis 2013; 13: 8.

7. Van Bambeke F, Balzi E, Tulkens PM. Antibiotic efflux pumps. Biochem Pharmacol 2000; 60: 457-70.

8. Aathithan S, French GL. Prevalence and role of efflux pump activity in ciprofloxacin resistance in clinical isolates of Klebsiella pneumoniae. Eur J Clin Microbiol Infect Dis 2011; 30: 745-52. 